\section{Lærerikt om helse og politikk}

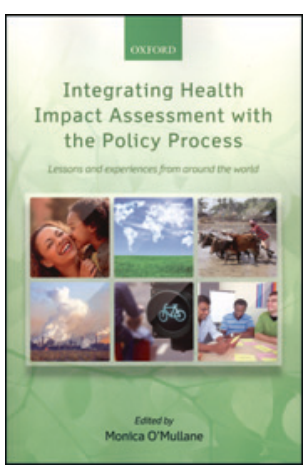

Monica O'Mullane, red.

Integrating health impact assessment with the policy process

Lessons and experiences from around the world. 218 s, tab, ill. Oxford: Oxford University Press, 2013. Pris GBP 30

ISBN 978-0-19-963996-0

Health impact assessment (HIA), på norsk helsekonsekvensutredninger (HKU), er utviklet for å støtte politikkutvikling og søker å kartlegge konsekvenser for folkets helse av planer, prosjekter, tiltak og politikk innenfor ulike sektorer. Det endelige målet er på en systematisk og omfattende måte å predikere helsekonsekvenser og informere om dette i beslutnings- og politiske prosesser.

I Norge ble helsekonsekvensutredninger en forskriftsfestet del av planlegging knyttet til plan- og bygningsloven fra 2008, og ligger implisitt også i folkehelseloven. Slik sett er Norge kommet langt i forhold til flere andre land som har skrinnere lovgivning på feltet. I Norge, som i flere andre land, foregår det arbeid med hvordan helse skal dekkes (indirekte via miljø, gjennom epidemiologi, sosiologi og/eller økonomi eller annet), analysemetodikk og ikke minst hvordan slike konsekvensutredninger skal kommuniseres og integreres i politikkutviklingen.

I et introduksjonskapittel redegjør forfatterne kort for historisk og metodisk grunnlag for helsekonsekvensutredninger. I den resterende delen presenterer de erfaringer fra praksis og forskning på forholdet mellom helsekonsekvensutredninger og politikk i ulike land over hele verden. Tross presentasjon av landenes politiske og forvaltningsmessige systemer er kapitlene rimelig korte, og de er bygd opp med sjekklister, anbefalinger og læringspunkter som befordrer både forståelse og anvendelse.

Styrken er at bidragsyterne, uten et for omfattende sideantall, gir et bredt empirisk tilfang i forhold til å sette teori ut i praksis på et tverrfaglig krevende felt som spenner over et stort forvaltningsspekter. Slik sett dekker boken både folkehelse, miljø- og samfunnsvitenskapelige disipliner og vil være interessant for aktører innenfor både fag, forvaltning og politikk, forskning og undervisning. Boken bygger opp under Verdens helseorganisasjons konsept Helse $i$ all politikk, men er like relevant for Norge som har endret konseptet noe til Helse $i$ alt vi gjør.

For den som vil gå dypere inn i teori, er det behov for å supplere med annen litteratur, noe det er henvisninger i teksten til. Ønsker man å gå inn på mer praktiske sider, er det også rikelig med henvisninger til aktuelle prosjekter.

Alt $i$ alt en bok som jeg anser som overkommelig, leseverdig og relevant, også for norske lesere med interesse og engasjement for helse, samfunn og politikk.

Betty Johanne Pettersen

Trondheim kommune

\section{Oppdatert lærebok i «farmasøytisk medisin»}

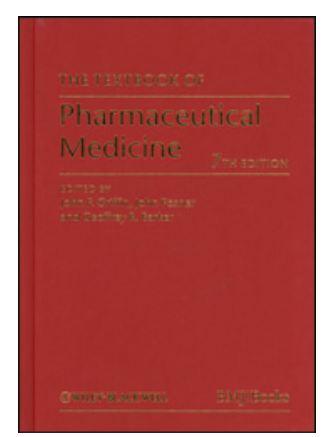

\author{
John P. Griffin, John Posner, \\ Geoffery R. Barker, red. \\ The textbook of pharmaceutical medicine \\ 7. utg. 854 s, tab, ill. Chichester: Wiley- \\ Blackwell, 2013. Pris GBP 188 \\ ISBN 978-0-470-65987-8
}

«Pharmaceutical medicine» er et begrep som ikke gir noen klar mening hvis man oversetter det direkte til norsk. Det handler om legemiddelutvikling, -utprøvning og -overvåking sett fra så vel legemiddelindustriens som legemiddelmyndighetenes side. Dette er en britisk klassiker på området og er nå kommet i 7. utgave - den første kom for 20 år siden. Den er primært skrevet som en lærebok for spesialistkandidater i «farmasøytisk medisin», som er en egen medisinsk spesialitet i Storbritannia.

Boken har tre hoveddeler: forskning og utvikling, lovgivning og regelverk og legemidler sett $i$ et markedsperspektiv. I tillegg inneholder den et appendiks med blant annet Helsinki-deklarasjonen og EU-direktivet om klinisk utprøving av legemidler.

Stoffvinklingen gjenspeiler at den primært er skrevet for britiske lesere. Dette spiller liten rolle når det gjelder kapitlene i del 1, som i stor grad handler om allmenngyldige forhold som preklinisk og klinisk utprøvning av legemidler, farmakokinetikk og statistikk. I del 2 handler det mye om EUs regelverk på området. Siden dette er fullt ut gjeldende i Norge, er mange av disse kapitlene også relevante for norske forhold. Det er imidlertid andre kapitler i denne delen som kun er relevante for helt spesielt interesserte, slik som omtalen av legemiddelmyndighetenes arbeid i USA, Japan og Australia. I del 3 er det noen kapitler som kan være interessante for norske lesere, som kapitlene om markedsføring av legemidler, formelle krav til produktmonografier og pakningsvedlegg samt bruk av legemidler på godkjenningsfritak. Men det er også lite relevante kapitler om blant annet den britiske ordningen for prisregulering og refusjon av legemiddelutgifter.

Egne kapitler om biologiske og biotilsvarende legemidler samt presentasjon av ny faktainformasjon innenfor en rekke andre områder viser at redaktørene har gjort en grundig revisjon og oppdatering forut for denne utgivelsen. De har også gjort en god jobb i å samordne og tilpasse bidragene fra de 50-60 forfatterne av enkeltkapitler.

Boken er solid innbundet, men den har mye og tettpakket tekst med uvanlig liten skriftstørrelse, smale marger og få tabeller og figurer. Den er trykt i svart-hvitt.

Det er neppe noe stort marked for denne utgivelsen i Norge. Mange av kapitlene er ikke relevante for norske forhold, mens andre er altfor detaljerte for andre enn dem som trenger dybdekunnskap på området. Den kan være av interesse for ansatte i legemiddelindustrien og hos legemiddelmyndighetene, og eventuelt også for dem som arbeider innenfor akademisk klinisk farmakologi og farmasi, men det vil for de aller fleste klare seg at den er tilgjengelig som oppslagsbok i avdelingenes referansebibliotek.

Olav Spigset

Avdeling for klinisk farmakologi

St. Olavs hospital 